Abstracta Iranica

Revue bibliographique pour le domaine irano-aryen

Volume 34-35-36 | 2017

Comptes rendus des publications de 2011-2013

\title{
Avraham Faust. The Excavations at Tel 'Eton (2006-2009): A Preliminary Report
}

\section{Astrid Nunn}

\section{(2) OpenEdition}

10 Journals

\section{Édition électronique}

URL : http://journals.openedition.org/abstractairanica/41563

DOI : 10.4000/abstractairanica.41563

ISSN : 1961-960X

Éditeur :

CNRS (UMR 7528 Mondes iraniens et indiens), Éditions de l'IFRI

Référence électronique

Astrid Nunn, «Avraham Faust. The Excavations at Tel 'Eton (2006-2009): A Preliminary Report », Abstracta Iranica [En ligne], Volume 34-35-36 | 2017, document 31, mis en ligne le 15 juillet 2016, consulté le 26 septembre 2020. URL : http://journals.openedition.org/abstractairanica/41563 ; DOI : https://doi.org/ 10.4000/abstractairanica.41563

Ce document a été généré automatiquement le 26 septembre 2020.

Tous droits réservés 


\title{
Avraham Faust. The Excavations at Tel 'Eton (2006-2009): A Preliminary Report
}

\author{
Astrid Nunn
}

\section{RÉFÉRENCE}

Avraham Faust. « The Excavations at Tel 'Eton (2006-2009): A Preliminary Report ». PEQ 143/3, 2011, p. 198-224.

1 Le Tel 'Eton est situé entre Lachish et Tell Beit Mirsim dans la Vallée du Shéphélah. L'Université Bar-Ilan de Beersheba y fouille depuis 2006. Le site fut occupé dès le Bronze Ancien. Après sa destruction par les Assyriens et un hiatus du VII ${ }^{e}$ au Ve $s$. il fut réoccupé à la fin de l'époque achéménide. C'est principalement la céramique trouvée dans les puits de l'Area $C$ et sur un mur massif de l'Area D qui indique un habitat modeste au $\mathrm{V}^{\mathrm{e}}$ et IV ${ }^{\mathrm{e}}$ s. av. J.-C.

\section{AUTEURS}

\section{ASTRID NUNN}

Université de Munich 